\title{
POSSIBILITY STUDY OF IMPLEMENTING VERTICAL CONSTRUCTED WETLAND FOR DOMESTIC WASTE WATER TREATMENT IN URBAN KAMPONG
}

\author{
Haryati Sutanto ${ }^{1}$, Paulus Bawole ${ }^{2}$ \\ ${ }^{1)}$ Faculty of Biotechnology, Duta Wacana Christian University Yogyakarta Jl. Dr. Wahidin \\ 5-25, Yogyakarta 55224 \\ ${ }^{2)}$ Faculty of Architecture \& Design Product, Duta Wacana Christian University Yogyakarta, \\ Jl. Dr. Wahidin 5-25 Yogyakarta 55224 \\ Email: haryati@staff.ukdw.ac.id ${ }^{1}$, paulus@staff.ukdw.ac.id ${ }^{2}$
}

Submitted:22-05-2019; Revised: 30-01-2021; Accepted: 23-07-2021

\begin{abstract}
The Indonesian Ministry of Environment in 2014 released study results that $60-70 \%$ of rivers in Indonesia have been polluted by domestic wastewater, which is not treated properly. Improper and inadequate wastewater treatment not only pollutes water resources and damages ecosystems, but can also pose a significant public health risk. The development of spontaneous settlements in urban kampong makes the environmental quality within the settlements getting worse and many people consider that the area of urban kampong is not habitable. The efforts to treat wastewater before being discharged into water bodies are very important. The study of "vertical constructed wetland" model using water plants which are also ornamental plants can be considered as an alternative system for household wastewater treatment in kampong settlements. The objective of the research is to develop an alternative model of wastewater treatment that can overcome the obstacles of implementing a wastewater treatment system in terms of cost and availability land. The result shows that the removal efficiency of BOD, phosphate and total coliform are $71.64 \%, 50,92 \%$ and $99.67 \%$ respectively. Since the research is still being conducted on a laboratory scale, the further study must be developed with real case studies in low income community settlements in Kampung Kota. Additionally, this research can give suggestions to local government an alternative policy to implement domestic waste water treatment plan in a densely populated settlement along the riverbank in the city.
\end{abstract}

Keywords: Kampong, Vertical Constructed Wetland, Urban, Treatment

*Corresponding author: haryati@staff.ukdw.ac.id ${ }^{1}$ and paulus@staff.ukdw.ac.id² Copyright @2021 THE AUTHOR(S). This article is distributed under a Creative Commons Attribution-Share Alike 4.0 International license. Jurnal Teknosains is published by the Graduate School of Universitas Gadjah Mada. 


\section{INTRODUCTION}

A city certainly experiences problems due to the rapid population growth which has an impact on aspects of life, especially with regard to settlements. Since 2007, more than half the world's population has lived in cities, and by 2030 the population in the region is projected to increase to 60 percent. UN demographers estimate that Asia and the Pacific dominated the city for the first time in history, because in 2019 more than 50 percent of the population lives in cities. The urban population in the region exceeds 2.3 billion, comprising 54 percent of all urban areas on the planet. By 2030 the population of cities in the region is expected to increase to more than 2.8 billion and by 2050 it will reach almost 3.5 billion (See Figure 1,) [1] Urban growth automatically influences the spatial development within the city, including the spatial form of spontaneous settlements inhabited by low-income people. Spontaneous settlements are also called low-income settlements which generally have minimal infrastructure facilities. [2]

The densely populated urban areas generally develop into low-income residential areas with very minimum infrastructure facilities. The settlement of low-income communities usually develops into densely populated slum areas

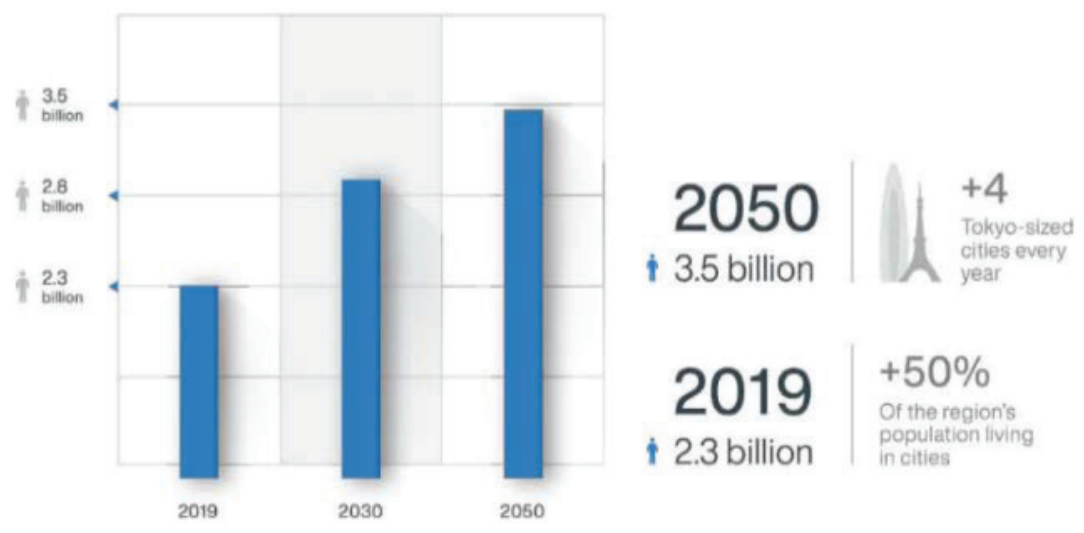

Figure 1.

Projected urban population in Asia and the Pacific, 2019 to 2050 Source: United Nation. The Future of Asian \& Pacific Cities.

ESCAP and UN-Habitat, 2019

Slum area is a condition of residential environment with a very unsuitable quality and has characteristics such as very high building density in a limited area, prone to social and environmental ailments, as well as very low quality of buildings, not serving adequate environmental infrastructure and endangering the lives and livelihoods of its inhabitants. [3] Many cities in Indonesia are crossed by rivers and the riverbanks are crowded with the settlements of low-income community usually called slum areas. The Indonesian Ministry of Environment in 2014 released study results that $60-70 \%$ of rivers in Indonesia have been polluted by domestic wastewater, which is not treated properly.
Sari et al. (2018) said that tap water distribution was poor in the slum area. Most of the dug wells and half of refill bottled water were contaminated. Estimated highest annual risk of infection due to fecal contamination would be caused by dug well and spring water since majority of the households did not use septic tank and disposed human waste directly to the river. [4] In addition, Surya B. et al. (2020) through their study in Makassar city found that slum settlements in watersheds and coastal areas as well as inadequate support for infrastructure services resulted in excessive groundwater use, soil pollution, and surface water quality pollution.[5] 
Constructed Wetland can be an alternative solution to the problem. Waste water treatment with the constructed wetland is very suitable to be implemented in lowincome housing areas, because of the providing materials, the effectiveness, the compatibility of the work system and the low operational costs. Its technology is natural, making its own advantages for the system that mimics the concept of natural wetlands. Besides, conventional wastewater treatment systems generally require energy and maintenance of mechanical components that need huge investments and high operational costs. Experiences show that wastewater treatment systems that exist in most developing countries fail to treat wastewater adequately. Some reasons for the failure of the system are due to high maintenance costs, lack of local experts and the poor governance. Compared to the conventional wastewater treatment systems, the wetlands can be built at a low cost, are easy to operate and maintain, so it is a good consideration to be applied in developing countries and to be one of the solutions to treat many types of liquid waste before being discharged into water bodies.[6]

The objectives of this study are to develop a waste treatment model that can overcome the obstacles of implementing a waste treatment system in terms of cost and availability land, and to test out whether the vertical constructed wetland system model using ornamental plants can be used as an alternative treatment for household wastewater.

In addition, the benefits of this study are to develop an alternative form of domestic wastewater treatment that is simple, does not require large costs, easy to operate but still can improve the quality of the wastewater and can be applied to urban village settlements.

\section{DISCUSSION OF BASIC THEORIES}

It is estimated that more than 1 billion people live in slum areas or live in inadequate housing. Slums are a physical reflection of the poverty and inequality of people living in a city. In developing and developed countries, urban housing, whether for rent or ownership, is be- coming increasingly unaffordable. Many cities have inadequate housing blocks and within the city homelessness is also growing. In some countries, young people continue to live with their parents for longer because they cannot afford to buy independent homes [1]

Based on the City without Slums Program (KOTAKU), to find out about the slums, there are 7 criteria plus one about the availability of green open space. The seven criteria are: building conditions, road conditions, environmental drainage conditions, drinking water supply conditions, sewage treatment conditions, solid waste management, fire safety conditions, and availability of green open space. One important aspect to deal with slums is dealing with household wastewater or commonly referred to as domestic wastewater. Wastewater treatment methods consist of several types, in general the processes used are physical, chemical, biological and a combination of the three to increase the efficiency of the waste treatment process. The process of treating wastewater with the activity of microorganisms is called a biological process. [7]

The wetland component in the research design can begin to be considered using ornamental plants in its treatment system to display aesthetic factors in the waste treatment design. There are some ornamental plants that can grow in an environment such as wetland that is always characterized by the presence of water in the system. The quality of household waste that has gone through a bioremediation process by simulating water plants, generally meets the requirements for release to the environment, both in terms of physical and chemical quality, as well as microbiological quality.[8]

\section{Constructed Wetland (CW)}

Constructed wetlands are treatment technologies designed to mimic the processes found in natural wetland ecosystems, built at a low cost, biologically treated wastewater. This CW system is now being implemented as a potential wastewater treatment alternative or can also be applied as an additional system for wastewater treatment. Today, CW is an innova- 
tive solution that promises to be implemented as a low-cost wastewater treatment system and is a sustainable treatment system to protect the environment that can be developed in many countries. CW has been used successfully to reduce environmental pollution by removing the content of various pollutants from wastewater such as organic compounds, suspended solids, pathogens, metals and nutrients. [9]

$\mathrm{CW}$ is a man-made wetland that takes advantage of the same principles as natural wetlands but in a more controlled environment. Currently there are many CW systems and natural wetland systems used for wastewater treatment [10] Plant species that can adapt and grow in the wetland system environment are plants that are able to adapt to environmental conditions that are always characterized by stagnant water conditions because they have intercellular tissue (aerenchym). This type of plant can bind oxygen from the air which will then be released in the rhizosphere. Roots of water weed plants are able to release oxygen to the rhizosphere so that it can support the process of nitrification, precipitation of Fe and Mn as well as the oxidation process of toxic compounds [11]

\section{RESEARCH METHODE}

This research method is motivated by the many dense low income community settlements that develop on the river banks. As has been discussed above that the slums of urban kampongs that develop on the banks of the river have limited land and the waste that is produced without being treated is directly thrown into the river.

Based on the conditions of the slums, the marginal people need a low-cost wastewater treatment. An alternative, a Constructed Wetland is to be developed. The operation cost is inexpensive and how to operate it is not too difficult.

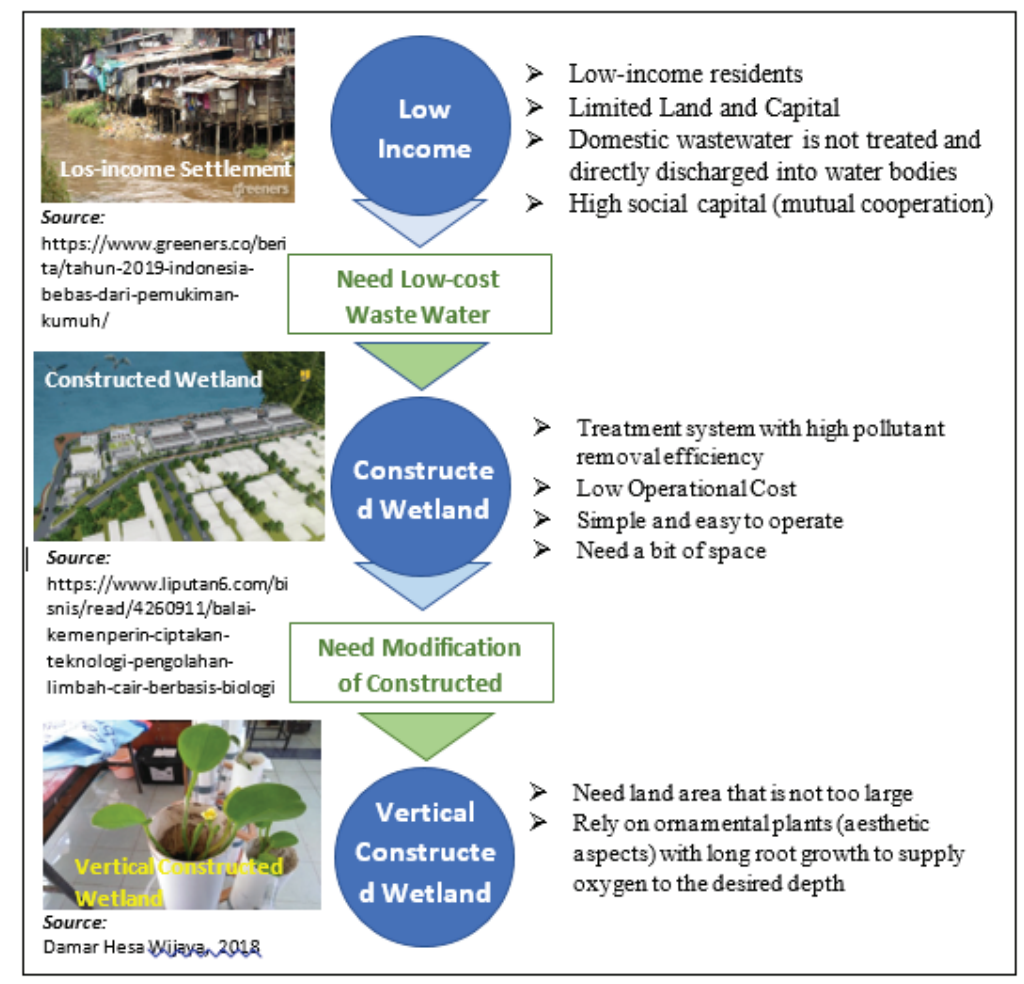

Figure 2.

Diagram of Possibility Study of Implementing Vertical Constructed

Wetland for $\mathrm{d}$

domestic wastewater treatments in urban Kampong

Source: Private Documentation 
As mentioned by Gkika et al. (2014), through their research about construction and operation costs of constructed wetlands, it shows that the construction and operation costs are respectively comparable and significantly lower than the corresponding costs of conventional facilities. The cost of $\mathrm{CW}$ wastewater treatment facilities comprises two parts namely capital cost and operation cost. The capital cost refers to the cost of the land needed for the installation of the facility, the construction cost, and engineer and contractor fees. .[12] While from cost analysis of constructed wetland pilot scale unit, Thiyagu and Vijayanand (2015) concluded also that constructed wetland is cost effective than conventional treatment plan. [10]

The problem is that the CW system usually requires a fairly large area of land, while in the slums area it is very difficult to get a large area for waste treatment. To meet the needs of domestic waste treatment is considered to modify the CW into Vertical Constructed Wetland, so that it can be used to treat domestic waste in low-income densely populated settlements in urban kampong (See Figure 2) This research was conducted on a laboratory scale using domestic waste from the Duta Wacana Christian University campus. It is expected that with the study of the possibility of implementing Vertical Constructed Wetland, a wastewater treatment solution for dense settlements with limited land can be carried out properly. The research methods carried out in detail can be explained as follows:

\section{Place of the Research}

The research was conducted at the Biotechnology laboratory - the Faculty of Biotechnology - Duta Wacana Christian University

\section{How to Conduct Research Research Design}

This research is an experimental work, by giving treatment to samples passing into the CW system consisting of media: sand, gravel and small stones combined with orna- mental plants: ornamental bananas (Heliconia psittacorum).

In this study the media used as a buffer media and grow ornamental plants are consisted of gravels with a diameter of $\pm 7 \mathrm{~cm}$, gravel with a diameter of $\pm 3 \mathrm{~cm}$, and small gravel with a diameter of $\pm 0.5-1 \mathrm{~cm}$ and paddy field soil with a ratio of 3: 2: 3: 1 (see figure $3)$, adjusted for reactor volume, with HRT of 3 days. The concept of flow in the system is the subsurface flow (SSF).

\section{Procedure}

The experiment was carried out by operating the wetland reactor filled with media arranged from the bottom up consisting of gravel with a diameter of $7 \mathrm{~cm}, 3 \mathrm{~cm}$, and $0.5-$ $1 \mathrm{~cm}$, then the top layer consisting of soil of rice fields. On the top is planted with ornamental bananas (Heliconia psittacorum)

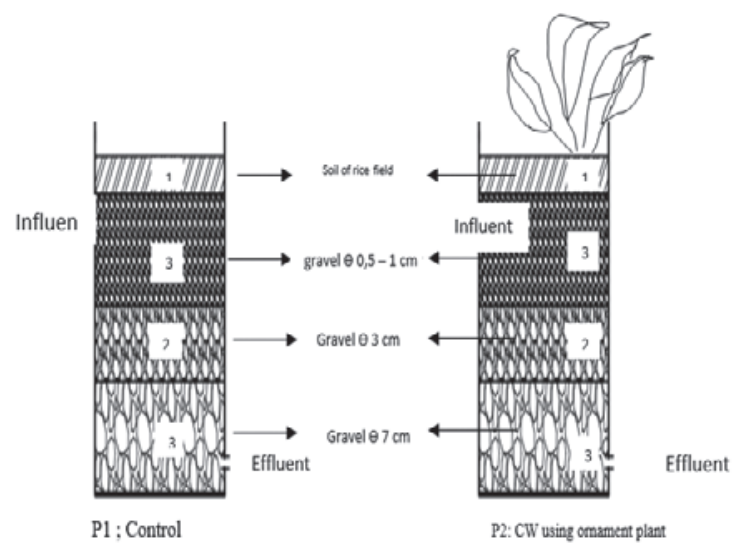

Figure 3.

Design of CW using ornamental plants

The wastewater used comes from wastewater in the infiltration well, Agape building at Duta Wacana Christian University representing domestic wastewater consisting of black water and gray water. Waste water flow is regulated so that a stay time of 3 days is reached.

The parameters observed and measured as characteristics of wastewater entering and leaving the system include: BOD, Phospate and Total Coliform. 


\section{RESULT OF THE REASERCH}

The measurement results of several parameters in "vertical constructed wetland" with laboratory scale can be seen in Table 1 below.

Table 1.

The average measurement results of some measured parameters and their removal efficiency

\section{Parameter DO ml/L}

\begin{tabular}{|l|c|c|c|c|c|}
\hline \multicolumn{1}{|c|}{ Parameter } & Influent & Effluent I & $\begin{array}{c}\text { Removal } \\
\text { Eficiency } \\
(\%)\end{array}$ & Effluent II & $\begin{array}{c}\text { Removal } \\
\text { Eficiency } \\
\text { (\%) }\end{array}$ \\
\hline pH & 7,85 & 7,89 & - & 7,48 & - \\
\hline Suhu ( $\left.{ }^{\circ} \mathrm{C}\right)$ & 27,69 & 27,75 & - & 27,60 & - \\
\hline DO (mg/) & 0,57 & 7,13 & - & 6,53 & - \\
\hline BOD (mg/) & 77,40 & 73,15 & 5,49 & 21,95 & 71,64 \\
\hline Phospat (mg/) & 4,34 & 2,34 & 46,08 & 2,13 & 50,92 \\
\hline $\begin{array}{l}\text { MPN Total koliform } \\
\text { (per 100ml) }\end{array}$ & 240.000 & 1346,63 & 99,44 & 780,25 & 99,67 \\
\hline
\end{tabular}

In treatment 1 the system without plants is considered as control and in treatment 2 is a "vertical constructed wetland" system using ornamental plants Heliconia psittacorum. Furthermore, the inlet from the Duta Wacana Christian University infiltration well is referred to influent, while the outlet from treatment 1 is called effluent I and the outlet from treatment 2 is called effluent II.

DO values indicate the amount of dissolved oxygen in the system. DO values greatly affect the processes that occur in waste treatment. If the $\mathrm{DO}$ value is too low then the activity of bacteria, especially aerobic bacteria, will have difficulty in degrading the organic compounds in the waste.

The dissolved oxygen value in effluent I and II has increased compared to the DO value of the influent. Based on these data it can be said that the constructed wetland system can increase the dissolved oxygen content by utilizing the photosynthesis process. By utilizing the lighting factor in this case sunlight, it proves that the wetland system has the advantage of a system that is considered as a low-cost waste treatment system. This system does not require expenses for energy supply except to use sunlight to increase the dissolved oxygen content in the system.

In the control treatment without plants showed an increase in dissolved oxygen content which is quite high as well, this can be made possible because of the presence of microorganisms that can carry out photosynthesis and produce oxygen, indicated by the number of biofilm attached to the walls of the system.

The dissolved oxygen value in treatment 2 shows lower results than in treatment 1 , the control, which is a without plant system (see Figure 4). It can be understood because the possibility of dissolved oxygen has been used by microorganisms to carry out the pro- 


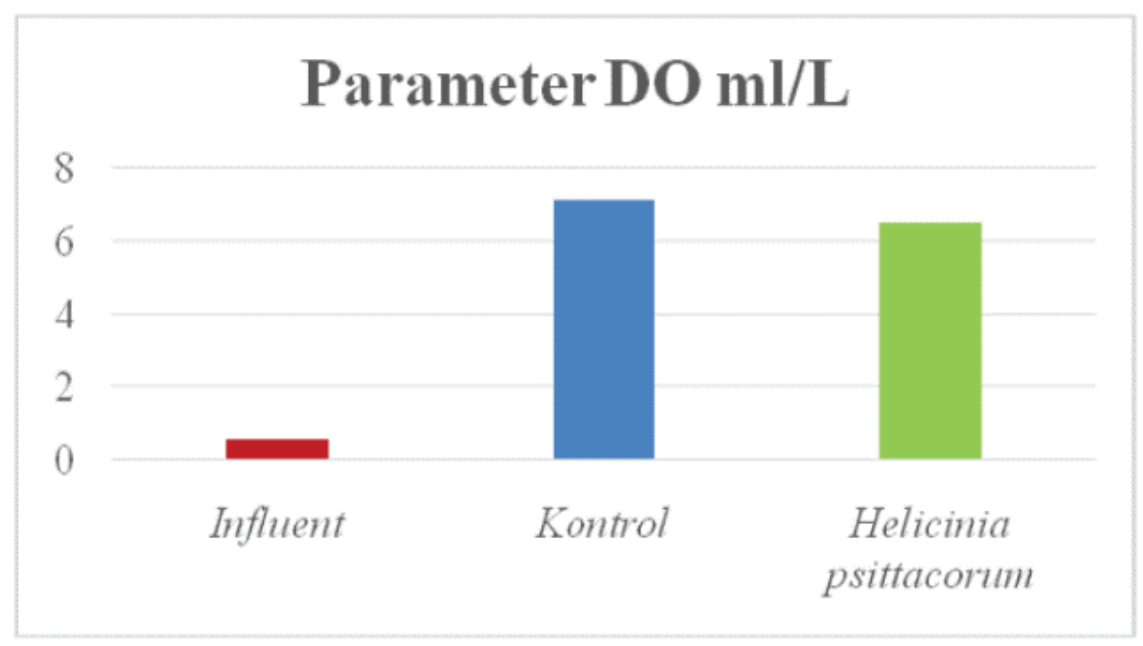

Figure 4.

The histogram of the increase in DO value

cess of degradation of organic material using oxygen.

The measured parameters show that the $B O D$ value has decreased. The greatest efficiency of BOD reduction in treatment 1 , the treatment of using Heliconia psittacorum. In the control system shows also the decreasing of BOD, although the removal efficiency was very small. This can be understood and explained because in the control treatment there are also microorganisms that can carry out degradation process (See table 1.)

Plants play a role in the supply of oxygen which in principle occurs due to the process of photosynthesis. Oxygen will flow to the roots of plants through the stem after diffusing through the pores of the leaves to form a rizosphere zone that is rich in oxygen throughout the root surface [13]

The release of oxygen by the roots of plants causes the water or the media around the root hair to have higher dissolved oxygen, thus allowing it to be a micro habitat for aerobic microorganisms to decompose organic matter. This can be seen by the removal efficiency of organic parameters.

The removal efficiency of phosphate content becomes the smallest value compared to the efficiency of decreasing the value of other parameters, but overall shows a process that results in reduced phosphate content after the waste is passed through the "vertical constructed wetland" system. Rhizophera microorganisms attached to the roots of aquatic plants can convert organic phosphates into orthophospates. Phosphate is needed by aquatic plants for photosynthesis, respiration, transfer and energy storage, so that phosphate absorption can occur quite a lot in the form of orthophospate.

The result also shows the decrease in the total number of coliform in all effluents compared to the amount in influents. Geen (2015) states that the main process involved in removing pathogens is the sedimentation process. This conclusion supports the results of observations which show a decrease in total coliform in all treatments both using plants and without plants. All treatments allow the sedimentation process to take place.[14]

Effluent of the system by using plants shows a greater reduction in efficiency compared to systems without plants. This shows the filtering process as another process that can occur in a "vertical constructed wetland" system. This screening process can occur not only in the wetland system media but also through the plant root structure. [15]

In Vymazal (2008) explained that the wetland system offers a combination of physical, chemical and biological factors that are suitable for eliminating pathogenic organisms. Physical factors include filtration mechanisms, exposure to ultraviolet radiation and 
sedimentation. [16] Chemical factors include oxidation and exposure to biocides which are excreted by some wetland plants. Biological removal mechanisms include antibiosis, predation by nematodes and protists, bacterial attack or natural death.

\section{CONCLUSION}

After finishing all discussions in previous, some conclusions can be seen as follows: "Vertical constructed wetland" model can be used as a domestic waste treatment system. All measured parameters in the effluent have decreased compared to the effluent wastewater, resulting in an improvement in the effluent quality of the effluent after the waste has passed through the "vertical constructed Wetland" system. The removal efficiency of BOD, phosphate and total coliform values respectively by $71.64 \% ; 50.92 \%$ and $99.67 \%$. The efficiency is greater than that of the control. The application of Vertical Constructed Wetland model is quite ideal, if it is implemented for the treatment of domestic wastewater in low-income community settlements in urban kampongs. Because this research is still being conducted on a laboratory scale, this study must be further developed with real case studies in low-income community settlements in Urban Kampung.

Due to conclusions above, the result of this research can give recommendations such as: Developing other research activities in the future about vertical Constructed Wetland which use other materials and vegetation as well as upscaling the laboratory scale. The local government can implement a policy to implement Vertical Constructed Wetland in densely populated low income settlements along the riverbanks within the city.

\section{BIBLIOGRAPHY}

[1] United Nations Human Settlements Programme, Annual Progress Report. UN-Habitat, 2019

[2] Bawole, P., et. al. "Harmonisasi Pengembangan Kampung Organik Berbasis Komunitas di Kota Yogyakarta," in Proceedings:
Seminar Nasional Riset dan Teknologi Terapan, Makasar, 2-3 Agustus 2017

[3] Fitria, N. \& Setiawan, R.P. "Permukiman Kumuh di Kelurahan Kapuk, Jakarta Barat." In Jurnal Teknik Pomits Vo. 3, No. 2, 2014.

[4] Sari S.Y.I., Sunjaya D.K., ShimizuFurusawa H., Watanabe C., Raksanagara A.S.Water Sources Quality in Urban Slum Settlement along The Contaminated River Basin in Indonesia: Application of Quantitative Microbial Risk Assessment. Journal of Environment and Public Health. 2018

[5] Surya B., Saleh H., Suriani S., Sakti H.H., Hadijah H., Idris M.Environmental Pollution Control and Sustainability Management of Slum Settlements in Makassar City, South Sulawesi, Indonesia. Land 9, 279. 2020

[6] Sudarsan JS, Roy RL, Baskar G, Deeptha VT, Nithiyanantham S. 2015. Domestic Wastewater Treatment Performance Using Constructed Wetland. Sustain. Water Resour. Manage 1.2015

[7] Hammer J.M \& Hammer,Jr. M.J. Water and Wastewater Technology. Pearson Education International, 2012

[8] Yusuf,G. Bioremidiasi Limbah Rumah tangga dengan Sistem Simulasi tanaman Air. Jurnal Bumi Lestari, Vol.8 No.2, 2008.

[9] Darajeh N.,Idris A., Nourani A., Sairi N.A. Modeling BOD and COD Removal from Palm Oil Mill Secondary Treatment in Floating Wetland by Chrysopogon zizaniodes (L.) Using Respone Surface Methodology.Journal Environmental Management 181, 2016.

[10] Thiyagu \& Vijayanand. Low Cost Domestic Wastewater Treatment Technique using Constructed Wetland. Trends in Bioscience 8, , 2015. 
[11] Kurniadie H.D. Teknologi Pengolahan Limbah. Penerbit Erlangga, 2017

[12] Gkika D., Gikas G.D.,, Tsihrintzis V.A.Construction and Operation Cost of Constructed Wetlands Treating Wastewater.Water science \& Technology 70.5 IWA Publishing 2014

[13] Suprihatin H.,2014. Penurunan Konsentrasi BOD Limbah Domestik menggunakan Sistem Wetland dengan Ranaman Hias Bintang Air (Cyperus alternifolius). Dinamika Lingkungan Indonesia, Volume 1, No.2

[14] Geen A., 2015. Using Wetlands to remove Microbial Pollutants from Farm Discharged Water. ANR Publication 8512, University of California.

[15] Weber,K.P. \& Legge R.L., 2008. Pathogen Removal in Constructed Wetlands. Researchgate

[16] Vymazal J., 2008. Constructed Wetlands for Wastewater Treatment: A Review. The 12th World lake Conference Proceeding 